\title{
Evaluation of Nutrient Contents of Amaranth Leaves Prepared Using Different Cooking Methods
}

\author{
Olumakaiye M. Funke
}

Department of Family, Nutrition and Consumer Sciences Faculty of Agriculture, Obafemi Awolowo University, Ile-Ife, Nigeria. Email: tunrayomakaiye@yahoo.co.uk

Received September $17^{\text {th }}, 2010$; revised March 23 ${ }^{\text {rd }}, 2011$; accepted March $28^{\text {th }}, 2011$.

\begin{abstract}
Amaranth is a commonly consumed vegetable in households in Southwestern Nigeria. Raw amaranth is known to be rich in micronutrients particularly Iron and Vitamin $C$, which are lost during cooking due to the method of preparation. Hence, this study was conducted to determine the method of preparation that best retains nutrients. Three common methods of preparing amaranth were identified; method 1 in which no heat was applied but amaranth leaves were finely chopped (samples A), method 2 which was steaming before chopping the leaves (sample B) and method 3 involved chopping of leaves before blanching (sample $C$ ). These three samples were subjected to proximate analysis and micronutrient determinations. Results were mean of three determinations. Result of proximate analysis showed that sample $B$ method of preparation has highest percentage of crude fat per gram of sample $(2.31 \pm 0.45)$, protein $(4.35 \pm 0.15)$ and fibre (1.09 \pm 0.06). Sample A has highest percentage of moisture (90.35 \pm 0.27$)$ and ash content (1.36 \pm 0.28$)$ while sample $C$ has highest percentage per gram of sample in carbohydrate $(4.89 \pm 1.21)$ only. Micronutrient determination results showed that sample A was highest in Vitamin C (1.57 $\mathrm{mg} \pm 0.06)$ and Iron (535.84 ppm \pm 123.42$)$, followed by sample $C(1.21 \pm 0.07)$ and $(501.88 \pm 215.19)$ respectively while sample $B$ had the least vitamin $C(0.79 \pm 0.06)$ and Iron (354.18 \pm 121.84$)$. The study showed that samples A best retained the nutrient contents of Amaranth leaves after preparation.
\end{abstract}

Keywords: Amaranth, Cooking, Micronutrient, Preparation, Proximate

\section{Introduction}

Vegetable is an important contributor to human well being. They are usually responsible for more subtle feeling of daily well being and for protection from long term degenerated diseases [1]. Vegetables are also the major contributor of edible plants to human health. They have always been taught to have large amount of vitamins and minerals like folic acid, vitamin A and vitamin C. Vegetables also have starch and cellulose present in them. They supply high amount of water and mineral elements, and the mineral elements in them contribute to the alkaline substance in the body and this enables them to maintain the acid-base balance of the body. The mineral elements like calcium, iron, sodium, magnesium, phosphorus, copper, cobalt, potassium, manganese and chlorine are present. Vegetables are also poor sources of calories except in roots and tubers.

Vegetables are usually grouped into three; 1) Green leafy vegetables for example pumpkin, amaranth, lettuce have high health value [2]. 2) Roots and tubers for ex- ample potatoes, carrots, yam and 3) Other vegetables like beans and peas.

Green leafy vegetables are the richest in carotene and the carotene depends on the green colour. They are fair sources of protein and good sources of vitamins and also minerals. Some contains anti nutrients that interfere with the absorption of some nutrients in diet [1]. These anti nutrients like phytic acid, oxalates, pro-anthrocyanidin, tannin and dietary fibres reduce the bio availability of the nutrients [3]. Aletar and Adeogun (1995) reported that anti nutritional phytochemical exhibit protective effects, thus making them to serve a dual purpose of reducing some essential nutrient and protecting the body against a number of biochemical, physiological and metabolic disorder. Green leafy vegetable acts as a buffer and maintains the proper alkalinity of the blood by balancing acidproducing foods like meats.

Amaranth is one of the most commonly consumed green leafy vegetable (GLV) in households in Osun state, Nigeria. There are about six species in cultivation and they protect against several disorders such as defective 
vision, respiratory infections, recurrent colds, retarded growth, functional sterility, bleeding tendencies, leucorrhoea, and premature ageing [2]. It is always available both in rainy and dry seasons, it is affordable and accessible. Amaranth requires little stress in preparation and can conveniently accompany any meals. It is eaten at any time of the day either as an accompaniment or a garnish in breakfast, lunch and dinner. It is a common vegetable for occasions in form of "Efo Riro" and can accompany all carbohydrate dishes in southwestern Nigeria.

Most people eat vegetables without getting the specific amount of nutrients from them. This is usually due to the differences in the methods of preparation. The Amaranth leaves, after eating should provide high protein per calorie consumed, high dietary fibre, high iron, low fats and very high vitamin C, Vitamin A, Folic acid and calcium.

This study basically was designed to assess the retention of nutritional contents of Amaranth leaves using various preparatory methods before cooking.

\section{Methodology}

The study was carried out Ile Ife, Osun State, Nigeria by the Department of Family, Nutrition and Consumer Sciences of the Obafemi Awolowo University, Ile Ife, Nigeria. The methodology for this study included both qualitative and quantitative.

\subsection{Focus Group Discussion}

Focus groups (FGs) are group discussions designed to learn about people's perception on a defined area of interest $[4,5]$. This was used to gain access to, and understand women's activities in the areas of vegetable preparation. The respondents, who were women, were selected from four areas in Ife township of Osun State, Nigeria; they are University Community, Ife Central, Ife East and Ife West areas. Each focus group consisted of 8 - 10 women. Eight FGs were conducted in all, two from each area. The aim and the purpose of the research were explained in every focus meeting. During the discussion, a flip chart was used to collect the names of most commonly consumed traditional vegetables and the methods of preparation prior to cooking. The most commonly consumed traditional vegetables are presented in Table 1 in stepwise order.

\subsection{Determination of Nutritional Quality}

The raw material which is bundle of amaranth was obtained from the local central market in Ile Ife, Nigeria.

Three commonly used methods of preparing amaranth in south-western Nigeria were identified and they are:

Method 1: The amaranth was cleaned to remove the woody or tough stalk. The leaves were finely chopped and washed in cold water in a bowl to remove the dirt,
Table 1. Stepwise ranking of the most commonly consumed traditional vegetables in the districts from FGDs.

\begin{tabular}{ccccc}
\hline $\begin{array}{c}\text { Traditional } \\
\text { Vegetable }\end{array}$ & $\begin{array}{c}\text { University } \\
\text { Community } \\
\mathbf{n}=\mathbf{4 0}\end{array}$ & $\begin{array}{c}\text { Ife } \\
\text { Central } \\
\mathbf{n}=\mathbf{3 4}\end{array}$ & $\begin{array}{c}\text { Ife } \\
\text { East } \\
\mathbf{n}=\mathbf{3 2}\end{array}$ & $\begin{array}{c}\text { Ife } \\
\text { West } \\
\mathbf{n}=\mathbf{3 3}\end{array}$ \\
\hline $\begin{array}{c}\text { Amaranth } \\
\text { (Amaranthus spp) }\end{array}$ & 38 & 34 & 31 & 30 \\
$\begin{array}{c}\text { Okra } \\
\text { (Abelmoschus spp) }\end{array}$ & 32 & 27 & 31 & 28 \\
*Water leave & 26 & 22 & 25 & 27 \\
$\begin{array}{c}\text { African egg plant } \\
\text { (Solanum spp) } \\
\text { *Bitter leave } \\
\text { (Launaea cornuta) }\end{array}$ & 18 & 14 & 19 & 18 \\
\hline
\end{tabular}

*Wild Vegetable that grows naturally without cultivation.

then drained. No heating was done. This was labelled as Sample A.

Method 2: The amaranth was cleaned to remove the woody or tough stalk. The leaves were steamed by pouring boiling water on the leaves which was left to steam for two minutes. The steamed leaves were cooled and finely chopped after draining off the water. This was labelled Sample B.

Method 3: The amaranth was cleaned to remove the woody or tough stalk. The leaves were finely chopped then blanched by heating the leaves in boiling water on fire for two minutes. The blanched leaves were then cooled. This was labelled as Sample C.

All the three samples were replicated.

Proximate analysis was carried out on the samples using the Association of Officials Analytical Chemist AOAC (1995) method, and mineral elements were also determined.

\subsection{Analysis of Data}

Data was entered and processed using SPSS version 11.0 (Statistical Package for the Social Sciences, Chicago, IL, USA). The statistical analysis was carried out using descriptive statistics of frequency, percentages, means and standard deviations. The frequency of occurrence and percentages on the various parameters were presented in tables. Since most of the traditional vegetables were named by their English or Yoruba names, scientific names of cultivated vegetables were determined and compared with other studies. [6-9]. Vegetables were counted as "units" rather than species [10].

\section{Results}

\subsection{Proximate Analysis}

\subsubsection{Moisture Content}

Data in Table 2 showed that moisture content of the dif- 
Table 2. Mean value of proximate analysis of Amaranth leaves.

\begin{tabular}{cccccc}
\hline Sample & Moisture & Crude fat & Crude protein & Ash & Crude fibre \\
\hline A & $90.35 \pm 0.27$ & $0.23 \pm 0.06$ & $3.16 \pm 0.28$ & $1.36 \pm 0.28$ & $0.77 \pm 0.00$ \\
B & $88.09 \pm 0.01$ & $2.31 \pm 0.45$ & $4.35 \pm 0.15$ & $1.31 \pm 0.11$ & $1.09 \pm 0.06$ \\
C & $88.98 \pm 0.24$ & $0.45 \pm 0.57$ & $4.24 \pm 0.00$ & $0.94 \pm 0.00$ & $0.90 \pm 0.64$ \\
\hline
\end{tabular}

ferent samples of prepared vegetable ranged from 88.98\% to $90.35 \%$ per gram of sample. Sample A had the highest moisture content $(90.35 \% \pm 0.24)$. This was followed by sample C $(88.98 \% \pm 0.24)$ while sample B had the lowest moisture content of $88.09 \pm 0.01$.

\subsubsection{Crude Fat Content}

Fat content of the samples ranged from $0.23 \%$ to $2.13 \%$. Sample B had the highest value $(2.13 \pm 0.45)$ followed by sample $\mathrm{C}(0.45 \pm 0.57)$ while sample A had the least $(0.23 \pm 0.06)$ as shown in Table 2.

\subsubsection{Crude Protein Content}

Protein content of the samples ranged from $3.17 \% \pm$ $4.35 \%$ as shown in Table 2. Sample B had the highest value of $4.35 \% \pm 0.15$, followed by sample $C(4.25 \% \pm$ 0.00 ), while sample A had the lowest value of protein $(3.17 \% \pm 0.92)$.

\subsubsection{Ash Content}

The ash content of the three samples ranged from $0.94 \%$ to $1.36 \%$ per gram of sample, which indicated the amount of micronutrient composition in the samples. Sample A had the highest value of $1.36 \% \pm 0.28$, followed by sample B with $1.31 \% \pm 0.01$ while sample $C$ had the lowest value $(0.94 \pm 0.00)$.

\subsubsection{Crude Fibre}

Crude fibre content of the amaranth as indicated in Table 2 ranged from $0.77 \%$ to $1.90 \%$ for the different samples. Sample B had the highest crude fibre content (1.09 \pm 0.06) followed by Sample C $(0.99 \pm 0.64)$ while Sample A had the least $(0.77 \pm 0.00)$.

\subsection{Micronutrient Determination}

\subsubsection{Vitamin C content}

Vitamin C content of amaranth leaves ranged from $0.79 \mathrm{mg}$ to $1.57 \mathrm{mg}$. Sample A had the highest value of Vitamin C (1.57 $\mathrm{mg} \pm 0.06)$ followed by Sample C $(1.21 \mathrm{~g} / \mathrm{mL} \pm 0.07)$ while sample $B$ had the lowest (0.79 mg \pm 0.06$)$.

\subsubsection{Iron Content}

Data in Table 3 indicated that Iron content of amaranth leaves ranged from $354.18 \mathrm{ppm}$ to $535.84 \mathrm{ppm}$. Sample A had the highest value of $535.84 \mathrm{ppm} \pm 23.42$ followed by sample C (501.88 $\mathrm{ppm} \pm 215.19)$ while sample B had the lowest value of $354.18 \mathrm{ppm} \pm 121.84$.

\section{Discussion}

Traditional vegetables provide low-cost quality nutrition for large parts of the population in both rural and urban areas [11]. In fact, all of these vegetables are good sources of micronutrients including iron and calcium as well as vitamin A, B C and E. One example is amaranth, which contains more of these nutrients compared to a typical exotic leafy vegetable e.g white cabbage [12]. As traditional vegetables can play such an important role, the methods of preparation should be considered.

The most important traditional vegetables mentioned in the four areas were listed in Table 2. Based on the ranking, only amaranth, was consistently mentioned in all areas, which was the most commonly consumed. The most important issues named by the women concerning the production of amaranth were yield, marketability, availability all year round in general, inputs required, availability and cost of seeds as well as resistance to drought, pests and diseases. In terms of consumption, the women regarded taste, nutrient content and cooking behaviour to be of importance.

Most of the work on the effects of processing on amaranth deals with effect of various preparation methods on the vitamin C content of amaranth spp [13]. Keshinro and Ketiku (1979) reported an 80.3\% loss of Vitamin C from parboiling for 5 minutes, this increased to $91.5 \%$ after final cooking for another 5 minutes. This was also found in the study by Ajayi and Osibanjo [14,15]. All these corroborated with findings from this study. It was found that generally Vitamin $\mathrm{C}$ are affected by temperature and prolonged heating; the reason why sample A in this study, which did not undergo any heat application had the highest Vitamin $\mathrm{C}$ content.

As much as $400 \mathrm{mg}$ of vitamin $\mathrm{C}$ can be consumed from food sources; however, doses from $400 \mathrm{mg}$ to $1 \mathrm{~g}$ are generally safe and well tolerated [16]. Amaranth vegetables are eaten and used for protection against res-

Table 3. Mean value of micronutrients determination of Amaranth leaves.

\begin{tabular}{ccc}
\hline Sample & Vitamin C & Iron \\
\hline A & $1.57 \pm 0.06$ & $535.84 \pm 23.42$ \\
B & $0.79 \pm 0.06$ & $354.18 \pm 121.84$ \\
C & $1.21 \pm 0.07$ & $501.88 \pm 215.19$ \\
\hline
\end{tabular}


piratory disorders, defective vision, recurrent colds, retarded growth and functional sterility.

Amaranths are sometimes recommended by doctors for people with low red blood cell count because vitamin C promotes iron absorption from the small intestine [16]. According to World Health Organisation, in developing countries, every second pregnant woman and about $40 \%$ of preschool children are estimated to be anaemic. In many developing countries, iron deficiency is aggravated by worm infections, malaria and other infectious diseases like tuberculosis. The major health consequences include poor pregnancy outcome, impaired physical and cognitive development, increased risk of morbidity in children and reduced work productivity in adults. Anaemia also contributes to $20 \%$ of all maternal deaths. Iron content of foods is the most important constituent of forming haemoglobin. Amaranth leaves are rich in iron and this is best retained using sample A method of preparation.

From this study, samples A method of preparation of amaranth leaves was the method that best retain the nutrients of concern in this study. Sample A method of preparation retained very high percentages of moisture, ash, vitamin C and Iron in them because amaranth was not subjected to any heating process. While sample B retains considerably high amount of fat, protein and crude fibre but low in moisture, carbohydrate and micronutrients (Vitamin C, Iron) contents. However, sample $\mathrm{C}$ retains low amount of nutrients after preparation but highest in carbohydrate.

Based on the study, emphasis should be placed on samples A method of preparation. Sample A method is recommended for people who require high amount of Vitamin C and Iron for their health status such as children, pregnant and lactating mothers.

It was concluded that a few precautions help reduce the losses associated with cooking. Amaranth leaves should be consumed rapidly, wash them quickly in fresh water before cutting. When possible steam or stew rather than boiling or blanching. The water from steaming should be used in cooking to make soup or sauce. Generally, long cooking or keeping vegetables hot for a long time has a destructive effect on the vitamins. All these have implication on food and nutrition promotion and communication among women.

\section{REFERENCES}

[1] B. Raheena, "Food, Nutrition and Dietetics," 2nd Edition, Sterling Publisher Private Limited, Delhi, 2007, pp. 106109.
[2] H. K. Bakhru, "Foods That Heal: The Natural Way to Good Health,” Orient Paperbacks Limited, New Delhi, 2007, pp. 87-109.

[3] A. A. Akindahunsi and S. O. Salawu, "Phytochemical Screening of Nutrient and Antinutrient Composition of Selected Green Leafy Vegetables," Africa Biotechnology, Vol. 4, No. 6, 2005, pp. 497-501.

[4] V. A. Aleter and O. A. Adeogun, "Nutrients and Anti Nutrient Components of Some Tropical Leafy Vegetable," Food Chemistry, Vol. 54, No. 4, 1995, pp. 375-379. doi:10.1016/0308-8146(95)99830-S

[5] M. D. Kaplowitz and J. P. Hoehn, "Do Focus Groups and Individual Interviews Reveal the Same Information for Natural Resource Valuation?” Ecological Economics, Vol. 36, No. 2, 2001, pp. 237-247. doi:10.1016/S0921-8009(00)00226-3

[6] Association of Official Analytical Chemists, "Official Methods of Analysis 16th Edition,” Association of Official Analytical Chemists International, Arlington, 1995.

[7] R. R. Schippers, “African Indigenous Vegetables, an Overview of the Cultivated Species," Revised Version on CD-ROM, Natural Resources International Limited, Aylesford, 2002.

[8] P. M. Maundu, et al., "The Biodervisy of Traditional Leafy Vegetables,” International Genetic Resource Institute, Rome, 1999a.

[9] C. K. Ruffo, et al., "Edible Wild Plant of Tanzania,” English Press, Nairobi, 2002.

[10] G. Keding, et al., "Traits and Use of Traditional Vegetables in Tanzania," Technical Bulletin No. 40, AVRDC-The World Vegetable Center, Taiwan, 2007, p. 55.

[11] J. A. Chweya and P. B. Eyzaguirre, "The Biodervisy of Traditional Leafy Vegetables,” International Genetic Resource Institute, Rome, 1999.

[12] K. Weinberger and J. Msuya, "Indigenous Vegetables in Tanzania: Significance and Prospects,” Technical Bulletin No. 31, AVRDC-The World Vegetable Center, Taiwan, 2004.

[13] M. Fafunso and O. Bassir, "Nutritional Qualities of Some African Edible Leafy Vegetables, Effect of Boiling on the Essential Amino Acid Composition of Their Extracted Protein,” 1976. http://www.nal.usda.gov/fnic/foodcomp

[14] O. O. Keshinro and A. O. Ketiku, "Effect of Traditional Cooking Method on Ascorbic Acid of Some Nigerian Leafy and Fruit Vegetable,” Food Chemistry, Vol. 4, No. 4, 1979, p. 303. doi:10.1016/0308-8146(79)90018-9

[15] S. O. Ajayi and O. Osibanjo, "Vitamin C Losses in Cooked Fresh Leafy Vegetables," Food Chemistry, Vol. 5, No. 3, 1980, p. 243. doi:10.1016/0308-8146(80)90016-3

[16] Nestle Food and Nutrition Communication, "Periodical of Nestle,” July Edition, 2007, pp. 8-13. 